\title{
Living in a hot redox soup: antioxidant defences of the hydrothermal worm Alvinella pompejana
}

\author{
Bertrand Genard $^{1,2, *}$, Benjamin Marie ${ }^{3,4}$, Eléonore Loumaye $^{1}$, Bernard Knoops $^{1}$, \\ Pierre Legendre $^{5}$, Franck Zal ${ }^{3, * *}$, Jean-François Rees ${ }^{1,6, * *}$ \\ ${ }^{1}$ Institut des Sciences de la Vie (ISV), Université catholique de Louvain, 1348 Louvain-la-Neuve, Belgium \\ ${ }^{2}$ Institut des sciences de la mer, Université du Québec à Rimouski, G5L 3A1 Rimouski (Québec), Canada \\ ${ }^{3}$ Institut des sciences de la mer, Equipe Ecophysiologie: Adaptation et Evolution Moléculaires, \\ UPMC - CNRS UMR 7127 - INSUE, Station Biologique, 29682 Roscoff, France \\ ${ }^{4}$ UMR 7245 MCAM MNHN/CNRS, Muséum National d'Histoire Naturelle, 75005 Paris, France \\ ${ }^{5}$ Département des sciences biologiques, Université de Montréal, H3C 3J7 Montréal (Québec), Canada \\ ${ }^{6}$ Earth and Life Institute (ELI) and Centre de Recherche en Biodiversité (BDIV), Université catholique de Louvain, \\ 1348 Louvain-la-Neuve, Belgium
}

\begin{abstract}
The hydrothermal Pompeii worm Alvinella pompejana lives very close to the walls of black smokers and is therefore exposed to high-temperature venting fluid containing high concentrations of sulphides and metals. The highly aerobic metabolism of these annelids, together with these extreme physico-chemical conditions, theoretically accelerates redox processes in and around the worm, potentially increasing oxidative threat by reactive oxygen species (ROS). This prompted us to analyse activity of antioxidant enzymes in A. pompejana tissues and investigate whether they are adjusted to the endogenous production of ROS by oxidative phosphorylations and/or to the environmental conditions. This was investigated by comparing antioxidant and metabolic enzyme activities in gills, head, body wall, pygidium and guts of $A$. pompejana collected at different vent sites of the East Pacific Rise. The antioxidant defence arsenal of A. pompejana is peculiar, showing very low catalase (CAT) activity and very high superoxide dismutase (SOD) activity in most tissues. It is very likely that CAT is not expressed in A. pompejana, as this haemic enzyme could be inhibited by the high sulphide concentrations prevailing in the worm's environment. A. pompejana does not compensate for the low hydrogen peroxide scavenging activity of CAT by higher glutathione peroxidase (GPX) activity levels. This latter enzyme correlates well with cytochrome $c$ oxidase and citrate synthase in most tissues, suggesting that oxidative metabolism represents the main source of peroxides managed by GPX. On the contrary, SOD shows no correlation with any metabolic enzyme and is likely adjusted to respiration-independent ROS generation. Source variations in enzyme activities are mainly observed in the animal's gills and gut, possibly reflecting differences in the vent fluid thermal regime and/or chemistry.
\end{abstract}

KEY WORDS: Deep-sea hydrothermal vent · Oxidative stress · Antioxidant defences · Metabolism • Alvinellid · Polychaete

\section{INTRODUCTION}

Hydrothermal vents are extreme environments in many aspects. High pressure, elevated temperatures, high concentrations of toxic substances, such as sulphide, metals and radioisotopes, and low $\mathrm{pH}$ prevail in these chemosynthesis-based ecosystems (Le Bris et al. 2006, Fisher et al. 2007, Demina et al. in press). On theoretical grounds, these physico-chemical conditions at vents are believed to favour redox processes leading to the formation of reactive oxygen species (ROS). Indeed, the occurrence of oxygen in 
seawater and millimolar sulphide concentrations in venting fluid should promote the production of highly reactive intermediates such as thiyl radicals (Giles et al. 2002, Gruhlke \& Slusarenko 2012). These can initiate chain reactions that peroxidise cellular lipids (Schöneich et al. 1989, Tweeddale et al. 2007). Sulphides and ROS can also interact with transition metals, which are abundant in the surrounding waters and in animal tissues, especially in gut contents, generating damaging radicals (Halliwell \& Gutteridge 1986, Adly 2010). All these factors suggest that vent animals are very likely to encounter high levels of toxic derivatives of oxygen and sulphur, but very little is known about their antioxidant defence mechanisms. Blum \& Fridovich (1984) detected superoxide dismutase (SOD) and glutathione peroxidase (GPX) activity in tissues of the hydrothermal vent clam Calyptogena magnifica and tubeworm Riftia pachyptila. This study was not followed by other analyses of antioxidant systems of vent organisms until the work of Bebianno, Company and colleagues. Their investigations of the antioxidant enzyme arsenal of the vent mussel Bathymodiolus azoricus (Company et al. 2004, 2006a,b,c, 2007, 2008, 2010, Bebianno et al. 2005) indicated that these mussels possess the classical antioxidant defence enzymes, comprising SOD, GPX and catalase (CAT). Their work suggests that the relative abundance of these enzymes in mussel tissues varies between venting sites, in relation to the abundance of metals such as $\mathrm{Fe}$ in the tissues (Bebianno et al. 2005, Cosson et al. 2008), confirming the occurrence of exogenous oxidative stress sources. Moreover, a recent transcriptomic approach using cDNA from the hydrothermal worm Alvinella pompejana showed that a major part of the annotated transcripts were directly related to oxidative stress, illustrating the importance of antioxidant processes in its adaptation to its extreme environment (Gagnière at al. 2010).

Beside the exogenous threat, endogenous production of ROS by mitochondrial respiration could be high in hydrothermal vent thermophilic animals. Indeed, the presence of sulphide in the alvinellid environment can also affect the respiration process by inhibiting the complex IV cytochrome oxidase, potentially leading to an increase in endogenous ROS production, as previously observed in the shallow-water annelids Arenicola marina and Glycera dibranchiate (Abele-Oeschger 1996, Völkel \& Grieshaber 1997, Julian et al. 2005, Joyner-Matos \& Julian 2011). The possible impact of high endogenous ROS production by cellular respiration on the expression of antioxidant enzymes has not yet been considered in hydrothermal vent organisms. The Pompeii worm Alvinella pompejana lives in a tube attached at the warmest end of the animal-colonised zone of the active chimneys along the East Pacific Rise (EPR). In situ temperatures recorded inside the tube of Alvinella are as high as $80^{\circ} \mathrm{C}$, suggesting that the worm's habitat is flushed with high temperature (Cary et al. 1998, Di Meo-Savoie et al. 2004, Le Bris et al. 2005, Pradillon et al. 2009). A. pompejana is an active, highly aerobic worm (Jouin-Toulmond et al. 1996, Hourdez et al. 2000, Le Bris \& Gaill 2007), but spends most of its time inside its tube, expanding its large gills only for very short periods (Desbruyères et al. 1998, Pradillon et al. 2005, Le Bris \& Gaill 2007), probably to avoid the toxic effects related to potential ROS production from respiration in gills when exposed to the hot hydrothermal fluid outside the tube. The correlations between oxidative metabolism and antioxidant activities have been previously investigated in the alvinellid Paralvinella grasslei exposed to varying oxygen concentration in hyperbaric chambers (Marie et al. 2006). This study indicated that GPX and the very low CAT-like activities were correlated to citrate synthase (CS) and cytochrome $c$ oxidase (COX) activities, thus reflecting the importance of respiration as a ROS source. On the other hand, SOD activity levels were not linked to those of metabolic enzymes in any tissue, suggesting that this activity could respond to other threats, possibly exogenous.

The aim of the present study was to determine (1) the levels of metabolic and antioxidant enzyme activity in Alvinella pompejana, (2) if these activities are equally active in the tissues, (3) the possible link between antioxidant enzyme activities and the aerobic metabolic activity of the tissues, and (4) the occurrence of significant variations between different vents in these activities.

\section{MATERIALS AND METHODS}

\section{Animal collection}

Collection of Alvinella pompejana (22 individuals; body weight $729 \pm 443 \mathrm{mg}$ and size $5.75 \pm 0.91 \mathrm{~cm}$ ) was performed at the Elsa $\left(12^{\circ} 48.14^{\prime} \mathrm{N}, 103^{\circ} 56.31^{\prime} \mathrm{W}\right.$; $\mathrm{n}=6)$, Herisson $\left(12^{\circ} 49.34^{\prime} \mathrm{N}, 103^{\circ} 56.67^{\prime} \mathrm{W} ; \mathrm{n}=6\right)$, Julie $\left(12^{\circ} 49.01^{\prime} \mathrm{N}, 103^{\circ} 56.58^{\prime} \mathrm{W} ; \mathrm{n}=4\right)$ and Parigo $\left(12^{\circ} 48.60^{\prime} \mathrm{N}, 103^{\circ} 56.43^{\prime} \mathrm{W} ; \mathrm{n}=6\right)$ vent sites on the EPR during the PHARE cruise (May 2002), using the manipulated arm or the slurp gun of the ROV Victor 6000 . Animals were brought from $2600 \mathrm{~m}$ to the sur- 
face in watertight and temperature-insulated containers. On board the RV 'Atalante', they were quickly transferred to a cold room $\left(10^{\circ} \mathrm{C}\right)$ and animals of similar size range were selected, then dissected on ice. Collected tissues (gill, head, body wall, pygidium and gut) were immediately frozen in liquid nitrogen and kept at $-80^{\circ} \mathrm{C}$ in the laboratory until analysis.

\section{Sample preparation}

Tissues were weighed and homogenised $(\mathrm{w} / \mathrm{v}=$ 1:5) in phosphate-buffered saline, $\mathrm{pH} 7.4$, containing $1 \%$ Triton X-100. An aliquot of the homogenate was used for the determination of protein content (Lowry et al. 1951), and the remainder was centrifuged at $15000 \times g\left(15 \mathrm{~min}, 4^{\circ} \mathrm{C}\right)$. The supernatant was used for enzyme activity assays. Enzymatic activity measurements were performed at $25^{\circ} \mathrm{C}$ in order to allow comparisons with previous investigations.

\section{Biochemical assays}

\section{CAT assay (EC 1.11.1.6)}

CAT activity was measured by chemiluminescence according to the method of Janssens et al. (2000). The consumption of $\mathrm{H}_{2} \mathrm{O}_{2}$ was measured at $25^{\circ} \mathrm{C}$ on a PCcontrolled microplate luminometer (Berthold LB96P). Firstly, $50 \mu \mathrm{l}$ of $1 \mu \mathrm{mol} \mathrm{l}^{-1} \mathrm{H}_{2} \mathrm{O}_{2}$ was added to $50 \mu \mathrm{l}$ of sample diluted in $100 \mu \mathrm{l}$ of $100 \mathrm{mmol} \mathrm{l}^{-1}$ phosphate buffer, $\mathrm{pH}=7.8$, containing $0.6 \mathrm{mmol} \mathrm{l}^{-1}$ EDTA. After $30 \mathrm{~min}$ incubation at $25^{\circ} \mathrm{C}$, the injection of $50 \mu \mathrm{l}$ of $20 \mathrm{mmol} \mathrm{l}^{-1}$ luminol and $11.6 \mathrm{U} \mathrm{ml}^{-1}$ horseradish peroxidase produced an emission of light at an intensity proportional to the remaining quantity of $\mathrm{H}_{2} \mathrm{O}_{2}$. $\mathrm{H}_{2} \mathrm{O}_{2}$-consuming activity in samples was estimated from a standard curve made with purified bovine liver solubilised in PBS-Triton buffer.

\section{SOD assay (EC 1.15.1)}

The spectrophotometric method of Flohé \& Ötting (1984) was adapted for microplate measurements. The assay is based on the competition between SOD and oxidised cytochrome $c$ for $\mathrm{O}_{2}{ }^{\circ-}$ generated by the reaction of hypoxanthine with xanthine oxidase (EC 1.1.3.22). The reduction rate of cytochrome $c(2 \mu \mathrm{mol}$ $\left.\mathrm{l}^{-1}\right)$ was measured at $550 \mathrm{~nm}\left(25^{\circ} \mathrm{C}\right)$, in $180 \mu \mathrm{l}$ of $50 \mathrm{mmol} \mathrm{l}^{-1}$ phosphate buffer, $\mathrm{pH}=7.8$, with $0.5 \mathrm{mmol}$ $\mathrm{l}^{-1}$ EDTA, $5 \mu \mathrm{mol} \mathrm{l^{-1 }}$ hypoxanthine and $10 \mu \mathrm{l}$ diluted sample. The reaction was initiated by injecting $10 \mu \mathrm{l}$ xanthine oxidase $\left(0.2 \mathrm{U} \mathrm{ml}^{-1}\right)$. SOD activity in samples was estimated with $\mathrm{Cu} / \mathrm{Zn}$-SOD purified from bovine erythrocytes.

GPX (EC 1.11.1.9)

GPX was measured spectrophotometrically by following the reduction rate of NADPH at $340 \mathrm{~nm}$ $\left(25^{\circ} \mathrm{C}\right)$, using the protocol of Paglia \& Valentine (1967) modified for 96-well microplates (Janssens et al. 2000). Fifteen $\mu \mathrm{l}$ of diluted sample were added to $120 \mu \mathrm{l}$ of $50 \mathrm{mmol} \mathrm{l}^{-1}$ Tris-HCl buffer, $\mathrm{pH}=7.6$, containing $0.1 \mathrm{mmol} \mathrm{l}^{-1}$ EDTA, $0.14 \mathrm{mmol} \mathrm{l} \mathrm{l}^{-1} \mathrm{NADPH}$, $1 \mathrm{mmol} \mathrm{l}^{-1}$ glutathione (GSH) and $1 \mathrm{U}$ GSH reductase (EC 1.6.4.2). The reaction was initiated by the addition of $15 \mu \mathrm{l}$ of $0.2 \mathrm{mmol} \mathrm{l}^{-1}$ t-butyl hydroperoxide. GPX activity was estimated using the molar extinction coefficient of NADPH $\left(6220 \mathrm{~mol}^{-1} \mathrm{l} \mathrm{cm}^{-1}\right)$.

Metabolic enzymes

Oxidative metabolism in the tissues was estimated from CS (EC 4.1.3.7) and COX (EC 1.9.3.1) activities, 2 mitochondrial enzymes well correlated to the oxygen consumption of tissues (Childress \& Somero 1979, Thuesen \& Childress 1993, 1994).

CS activity was measured according to the protocol of Childress \& Somero (1979) modified for multiwell plates. Twenty $\mu \mathrm{l}$ of diluted sample was added to $160 \mathrm{\mu l}$ of Tris-HCl buffer $\left(100 \mathrm{mmol} \mathrm{l}^{-1}, \mathrm{pH}=8\right)$ containing $15 \mathrm{\mu mol} \mathrm{l}^{-1}$ of 5,5'-dithio-bis(2-nitrobenzoic acid, DTNB) and $25 \mu \mathrm{mol} \mathrm{l}^{-1}$ acetyl-CoA. Consumption of acetyl-CoA was followed at $420 \mathrm{~nm}$ at $25^{\circ} \mathrm{C}$ after adding $20 \mu \mathrm{l}$ of $50 \mu \mathrm{mol} \mathrm{l^{-1 }}$ oxaloacetate. CS activity was estimated using the molar extinction coefficient of DTNB (13600 $\left.\mathrm{mol}^{-1} 1 \mathrm{~cm}^{-1}\right)$.

The spectrophometric assay method for COX of Yonetani (1967) was adapted for microplates. The oxidation of $0.1 \mathrm{~mol} \mathrm{l}^{-1}$ cytochrome $C$ solubilised in $180 \mathrm{\mu l}$ of Tris-HCl buffer $\left(50 \mathrm{mmol} \mathrm{l}^{-1}, \mathrm{pH}=7.6\right)$ was followed at $550 \mathrm{~nm}\left(25^{\circ} \mathrm{C}\right)$ after addition of $20 \mu \mathrm{l}$ of diluted sample. COX activity was estimated using the molar extinction coefficient of cytochrome $C$ $\left(19 \mathrm{~mol}^{-1} \mathrm{l} \mathrm{cm}^{-1}\right)$.

Lactate dehydrogenase (LDH, EC 1.1.1.27) was assayed in the tissues. The assay is based on the consumption of NADH for the reduction of pyruvate into lactate by LDH (Hand \& Somero 1983). The assay medium contained, in a total volume of $200 \mu \mathrm{l}$, $80 \mathrm{mM}$ Tris- $\mathrm{HCl}$ buffer $\left(\mathrm{pH} 7.5\right.$ at $\left.4^{\circ} \mathrm{C}\right), 2 \mathrm{mM}$ sodium 
pyruvate, $150 \mu \mathrm{M}$ NADH and $100 \mathrm{mM} \mathrm{KCl}$. The reaction was initiated with a small volume of the diluted sample $(20 \mu \mathrm{l})$ and the consumption of NADH was monitored at $340 \mathrm{~nm}$.

\section{Reagents}

All reagents were purchased from Sigma, except for Triton X-100, GSH and glutathione reductase, which were obtained from Boehringer. Protein content was determined spectrophotometrically with the Lowry Protein Assay (Bio-Rad) following the manufacturer's protocols.

\section{Statistical analyses}

The enzymatic activities are means of triplicate measurements per individual and are expressed relative to the protein content and the wet weight (wet wt) of the tissue. Although the expression of enzyme activity as a function of the wet wt seems to be more appropriate for comparing physiological capacities of the tissues, activities expressed relative to the protein content are often used in works published on different species. A canonical redundancy analysis (RDA) was performed as a form of multivariate analysis of variance (MANOVA), as proposed by Legendre \& Anderson (1999); the method is also described by Legendre \& Legendre (2012). This method uses permutation tests of significance, which remain valid for small samples and non-normally distributed data. The response matrix (Y) contained data for the 5 enzyme activi- ties (CS, COX, LDH, GPX and SOD) as columns, and 5 tissues from Alvinella worms at 4 vent sites (X). The explanatory matrices contained factors representing the tissues, the vent sites, and their interaction coded into contrast variables using Helmert coding. Due to unbalanced design Type III correction (anova.2way.unbalanced.R script) was used for sum of square calculation as suggested in Legendre \& Anderson (1999). Results of RDA were shown in a biplot graphs which present relationships (correlations) between the response variables and the explanatory variables. For graphical representation, explanatory variables were binary coded (dummy variables). The R-language packages rdaTest and anova.2way.unbalanced.R, available at http://adn.biol.umontreal.ca/ numericalecology/ FonctionsR/, were used to compute the canonical analyses and produce biplot graphs.

\section{RESULTS}

Enzyme activities expressed in $\mathrm{g}$ wet wt and $\mathrm{mg}$ protein are summarised in Table 1. CS, COX, LDH, GPX and SOD activities were detected in all tissues of Alvinella pompejana and varied by 1 order of magnitude between tissues. We were not able to determine CAT activity in all samples. Independently of these missing values, the measured CAT activity was low (35 to $70 \mathrm{U} \mathrm{g}^{-1}$ wet wt) and showed moderate differences between tissues. The occurrence of CAT activity was not clear and will be discussed below. CAT activity was therefore excluded from canonical RDA.

The first set of RDA analysis was performed on enzyme activity in tissues and vent sites as well as the

Table 1. Alvinella pompejana. Antioxidant and aerobic metabolism enzyme activities (mean $\pm \mathrm{SD})$ in tissues. Number of individuals is given in parentheses. All assays were carried out at $25^{\circ} \mathrm{C}$. CS $=$ citrate synthase, COX $=$ cytochrome $c$ oxidase, LDH $=$ lactate dehydrogenase, GPX $=$ glutathione peroxidase, $\mathrm{CAT}=$ catalase, $\mathrm{SOD}=$ superoxide dismutase. All enzyme activities were expressed in international units $(\mathrm{U})$

\begin{tabular}{|c|c|c|c|c|c|c|c|}
\hline \multirow{2}{*}{ Tissue } & \multirow{2}{*}{ Units } & \multicolumn{6}{|c|}{ - Enzyme } \\
\hline & & CS & $\mathrm{COX}$ & $\mathrm{LDH}$ & GPX & CAT & SOD \\
\hline Head & $\begin{array}{l}\mathrm{U} \mathrm{g}^{-1} \text { wet wt } \\
\mathrm{U} \mathrm{mg}^{-1} \text { protein }\end{array}$ & $\begin{array}{c}3.53 \pm 0.23(22) \\
0.068 \pm 0.005(22)\end{array}$ & $\begin{array}{c}0.53 \pm 0.09(22) \\
0.010 \pm 0.002(22)\end{array}$ & $\begin{array}{c}0.91 \pm 0.11(21) \\
0.017 \pm 0.002(21)\end{array}$ & $\begin{array}{c}0.43 \pm 0.04(21) \\
0.008 \pm 0.001(21)\end{array}$ & $\begin{array}{c}35 \pm 8(15) \\
0.66 \pm 0.15(15)\end{array}$ & $\begin{array}{c}474 \pm 65(22) \\
8.97 \pm 1.26(22)\end{array}$ \\
\hline Gills & $\begin{array}{l}\mathrm{U} \mathrm{g}^{-1} \text { wet wt } \\
\mathrm{U} \mathrm{mg}^{-1} \text { protein }\end{array}$ & $\begin{aligned} 9.51 & \pm 1.00(19) \\
0.139 & \pm 0.012(19)\end{aligned}$ & $\begin{aligned} 1.57 & \pm 0.37(19) \\
0.026 & \pm 0.007(19)\end{aligned}$ & $\begin{aligned} 1.46 & \pm 0.22(18) \\
0.021 & \pm 0.003(18)\end{aligned}$ & $\begin{aligned} 0.79 & \pm 0.12(18) \\
0.012 & \pm 0.002(18)\end{aligned}$ & $\begin{aligned} 52 & \pm 12(11) \\
0.74 & \pm 0.15(11)\end{aligned}$ & $\begin{aligned} 1439 & \pm 213(19) \\
23.10 & \pm 3.83(19)\end{aligned}$ \\
\hline Body wall & $\begin{array}{l}\mathrm{U} \mathrm{g}^{-1} \text { wet wt } \\
\mathrm{U} \mathrm{mg}^{-1} \text { protein }\end{array}$ & $\begin{aligned} 2.57 & \pm 0.26(21) \\
0.059 & \pm 0.009(21)\end{aligned}$ & $\begin{array}{c}0.46 \pm 0.08(21) \\
0.011 \pm 0.003(21)\end{array}$ & $\begin{array}{c}0.38 \pm 0.05(20) \\
0.009 \pm 0.002(20)\end{array}$ & $\begin{array}{c}0.17 \pm 0.02(19) \\
0.004 \pm 0.001(19)\end{array}$ & $\begin{array}{c}39 \pm 19(7) \\
0.84 \pm 0.41(7)\end{array}$ & $\begin{array}{c}919 \pm 196(21) \\
20.61 \pm 5.51(21)\end{array}$ \\
\hline Pygidium & $\begin{array}{l}\mathrm{U} \mathrm{g}^{-1} \text { wet wt } \\
\mathrm{U} \mathrm{mg}^{-1} \text { protein }\end{array}$ & $\begin{aligned} 2.74 & \pm 0.33(13) \\
0.076 & \pm 0.011(13)\end{aligned}$ & $\begin{aligned} 0.24 & \pm 0.04(13) \\
0.006 & \pm 0.001(13)\end{aligned}$ & $\begin{aligned} 0.24 & \pm 0.05(13) \\
0.007 & \pm 0.002(13)\end{aligned}$ & $\begin{aligned} 0.20 & \pm 0.02(13) \\
0.005 & \pm 0.001(13)\end{aligned}$ & $\begin{aligned} 37 & \pm 7(13) \\
1.04 & \pm 0.20(13)\end{aligned}$ & $\begin{array}{c}357 \pm 102(13) \\
8.86 \pm 2.25(13)\end{array}$ \\
\hline Guts & $\begin{array}{l}\mathrm{U} \mathrm{g}^{-1} \text { wet wt } \\
\mathrm{U} \mathrm{mg}^{-1} \text { protein }\end{array}$ & $\begin{aligned} 1.63 & \pm 0.28(20) \\
0.038 & \pm 0.007(20)\end{aligned}$ & $\begin{aligned} 0.78 & \pm 0.29(20) \\
0.016 & \pm 0.006(20)\end{aligned}$ & $\begin{array}{c}0.19 \pm 0.06(20) \\
0.005 \pm 0.001(20)\end{array}$ & $\begin{array}{c}0.41 \pm 0.02(20) \\
0.010 \pm 0.001(20)\end{array}$ & $\begin{array}{c}70 \pm 14(20) \\
1.73 \pm 0.37(20)\end{array}$ & $\begin{aligned} 2737 & \pm 487(20) \\
64.20 & \pm 11.81(20)\end{aligned}$ \\
\hline
\end{tabular}


interaction of both as explanatory variables. The results showed a significant effect for the tissue-site interaction ( $\mathrm{p}=0.001$ ), which led us to carry out 2 groups of analyses in order to investigate inter-tissue variations at each vent site on the one hand, and collection site effects on each tissue on the other hand. See Fig. 1 for enzymatic activities expressed by tissues and vent sites.

Significant RDA results were observed for tissue effect at each collection site where more than 52\% of total variance was explained by tissue differentiation (Fig. 2). At each collection site, good correlations were found between the activities of GPX, COX, CS and LDH where most of the variance (canonical axis 1) was explained by the differences between gills, head and the integuments (body wall and pygidium). The highest activities for these enzymes were recorded in gills followed by heads and integuments, with the exception of COX at the Elsa site, where only $25 \%$ of variance was explained by RDA, illustrating that the COX activity did not vary much between tissues in this location. At the 4 vent sites, a significant part of the total variance (canonical axis 2) was also explained by the higher SOD activity in guts compared to the other tissues. No correlations were found for SOD activity with the metabolic enzymes, suggesting that SOD activity was not related or associated with ROS generated during respiratory process.

The RDA analysis carried out to investigate the influence of the vent source on activities of metabolic and antioxidant enzymes showed significant differences only for gills and guts (Fig. 3). In gills, the differentiation between vent sites explained $39 \%$ of total variance based on CS, COX and GPX activities for the first canonical axis ( $27 \%$ of total variance) and on LDH and SOD for the second canonical axis $(11 \%$ of total variance). RDA explained 34 and $45 \%$ of COX and GPX total variance, respectively, on the first canonical axis. The biplot allowed gill COX and GPX activities to be classified in decreasing order as follows (1) Parigo, (2) Herisson and Julie, and (3) Elsa. For CS, $45 \%$ of total variance was explained by RDA on the first canonical axis, where highest activity was found in Parigo, followed by Julie and then by the 2 remaining sites. On the second canonical axis, the LDH activities (32\% of total variance on second axis) allowed Julie and Parigo to be differentiated from the other vents. For SOD, $13 \%$ of the variability was explained on the second axis by RDA, illustrating the low contribution to total variance. The collection site effect explained $27 \%$ of total variance observed in guts with $20 \%$ for the first axis and $5 \%$ for the second. SOD variations explained most of the differentiation between vent sites (69\% of SOD total variance on canonical axis 1), where highest values were observed in Elsa.

\section{DISCUSSION}

\section{Antioxidant abilities of Alvinella pompejana}

The pattern of antioxidant enzyme activity of Alvinella pompejana is peculiar, with a very low CAT activity and very high SOD activity. Compared to levels recorded in Paralvinella grasslei, A. pompejana SOD activity is even higher, markedly superior to values reported for non-hydrothermal annelids (Marie et al. 2006). On the other hand, it is not clear whether the observed hydrogen peroxide consumption by tissue homogenates actually reflects the occurrence of CAT. Activities are indeed very low for this enzyme, undetectable with classical spectrophotometric assay methods. Interestingly, in their pioneering work, Blum \& Fridovich (1984) were also not able to measure CAT activity in tissues of the hydrothermal vent clam Calyptogena magnifica and tubeworm Riftia pachyptila. They ascribed this observation to the inhibition of CAT by sulphide or degradation of this enzyme in samples. In contrast, studies performed on the vent mussel Bathymodiolus azoricus (Bebianno et al. 2005, Company et al. 2010) indicated that these mussels possess the classical antioxidant defence enzymes, comprising SOD, GPX and CAT. Compared to this lamellibranch, for which CAT activity ranged from 5 to $18.5 \mathrm{U} \mathrm{mg}^{-1}$ protein (Bebianno et al. 2005), activities detected in $A$. pompejana were even lower, below $2 \mathrm{U} \mathrm{mg}^{-1}$ protein. The low CAT activity in $A$. pompejana and P. grasslei, and its absence in Calyptogena magnifica and Riftia pachyptila (Blum \& Fridovich 1984) are intriguing and suggest that sample deterioration is not responsible for the absence of CAT in C. magnifica and R. pachyptila, as proposed by Blum \& Fridovich (1984). Indeed, no recovery of CAT activity was observed when $P$. grasslei was incubated on board in sulphide-free water. Rather, these very low CAT activities are most probably related to peculiarities in the hydrothermal environment. One possible cause is the abundance of sulphides in the hydrothermal environment and their inhibitory effect on heme-containing enzymes such as CAT (Beers \& Sizer 1954, Carlsson et al. 1988, Benetti et al. 2013). The susceptibility of CAT to sulphides could render this enzyme poorly efficient in the sulphide-rich hydrothermal environment (Le Bris et al. 2006, Fisher 

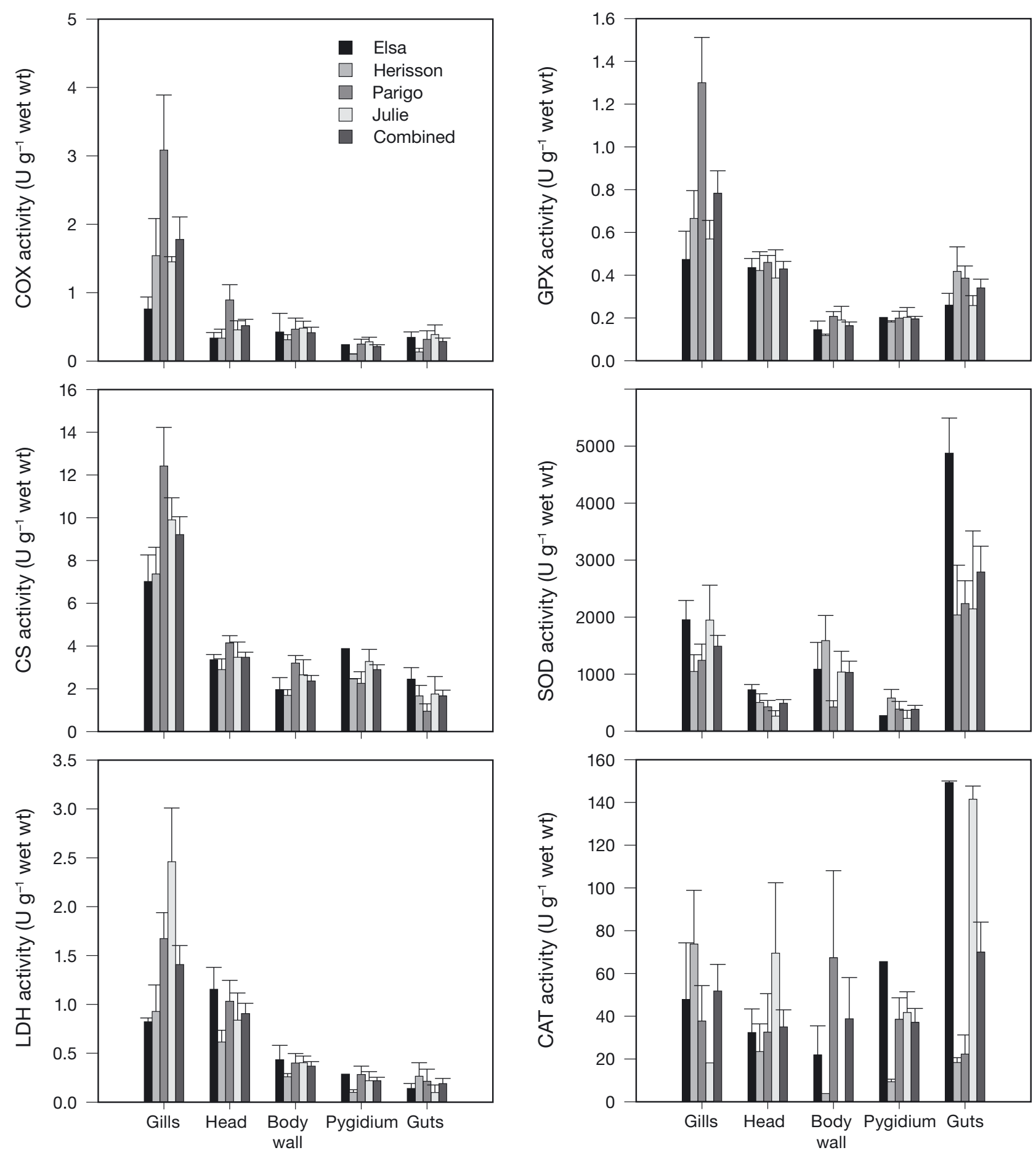

Fig. 1. Alvinella pompejana. Metabolic and antioxidant activities (mean $\pm \mathrm{SD}$ ) in several tissues for each collection vent and all vents combined. See Table 1 for enzyme abbreviations

et al. 2007). In addition, an exhaustive transciptomic of A. pompejana was unable to detect any CAT gene, while all other antioxidant enzyme-encoding mRNAs were clearly detected (Gagnière et al. 2010), suggesting that the CAT gene is poorly or not expressed in this animal. Interestingly, a CAT gene is also still lacking in the $R$. pachyptila symbiont metagenome sequence (Markert et al. 2007). In our case, the observed CAT-like activity might thus represent the consumption of $\mathrm{H}_{2} \mathrm{O}_{2}$ by other processes, such as 

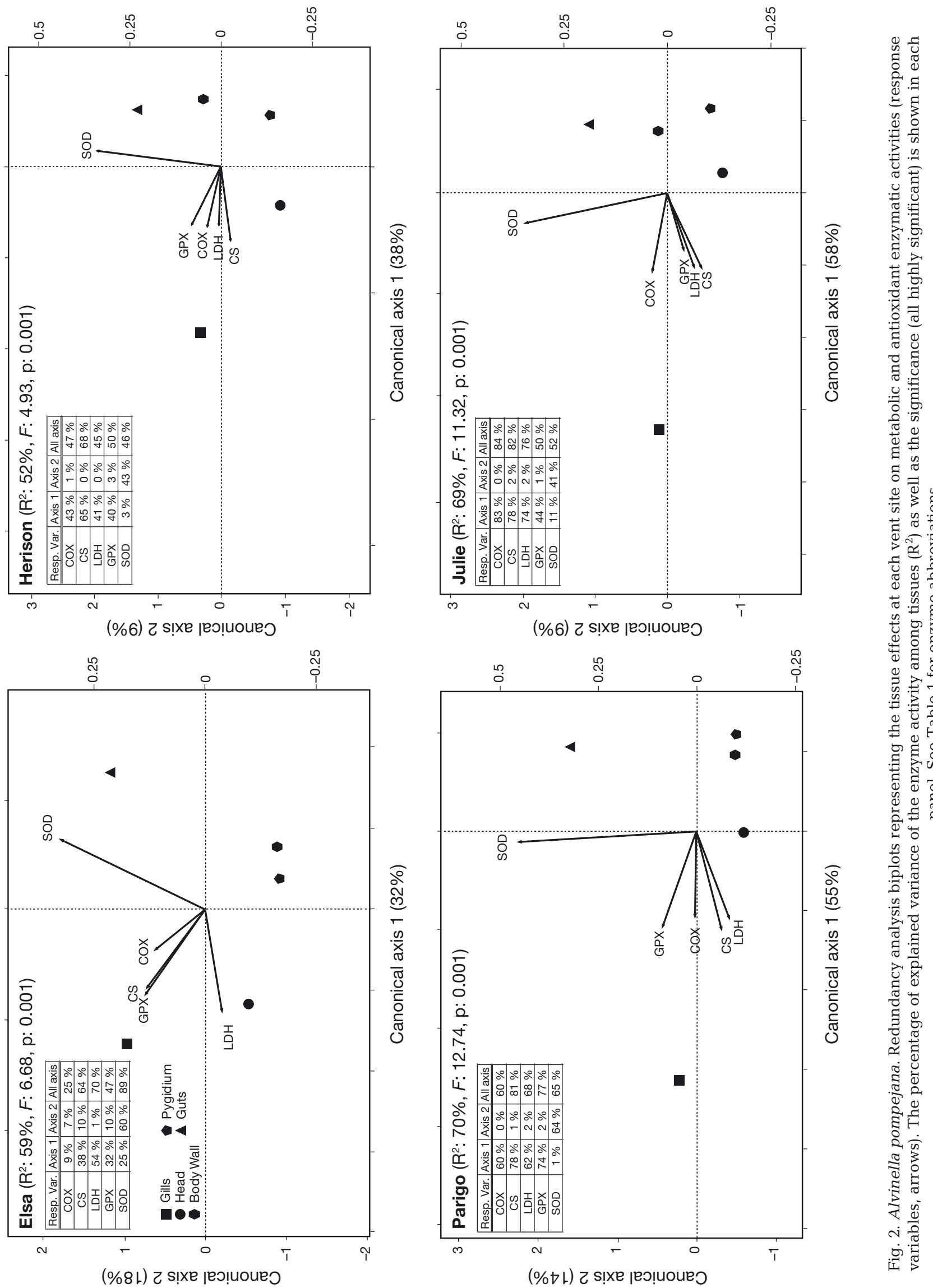


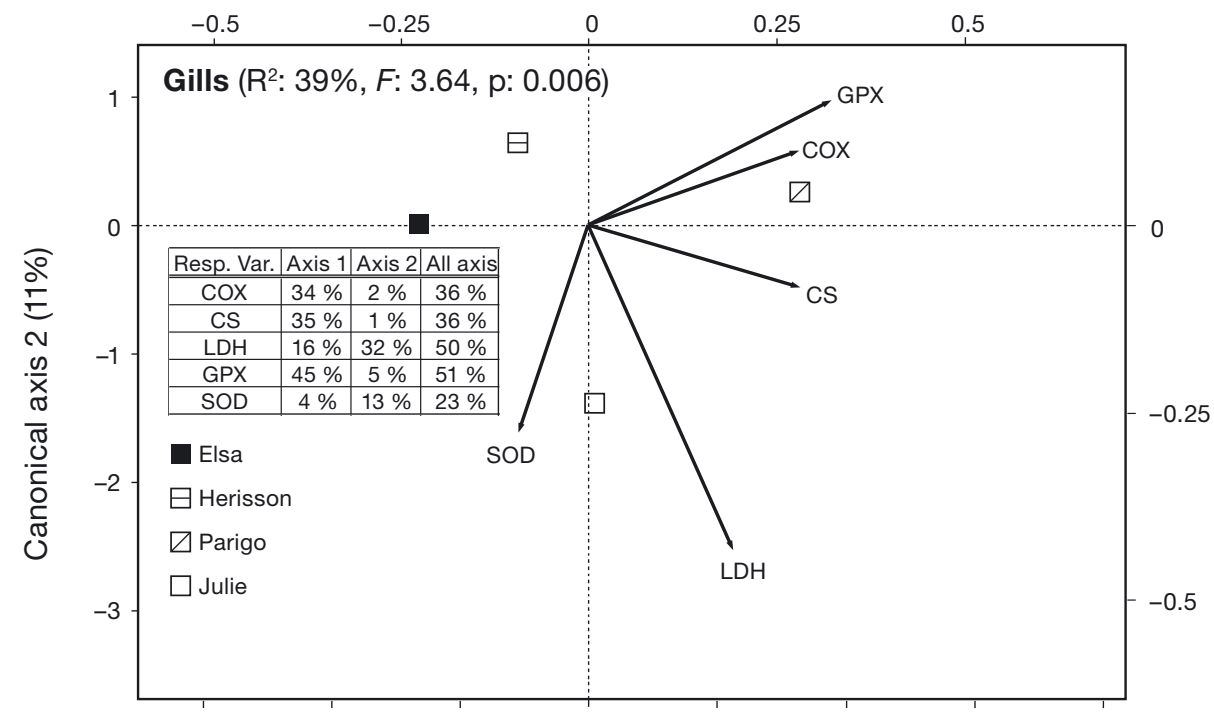

Canonical axis $1(27 \%)$

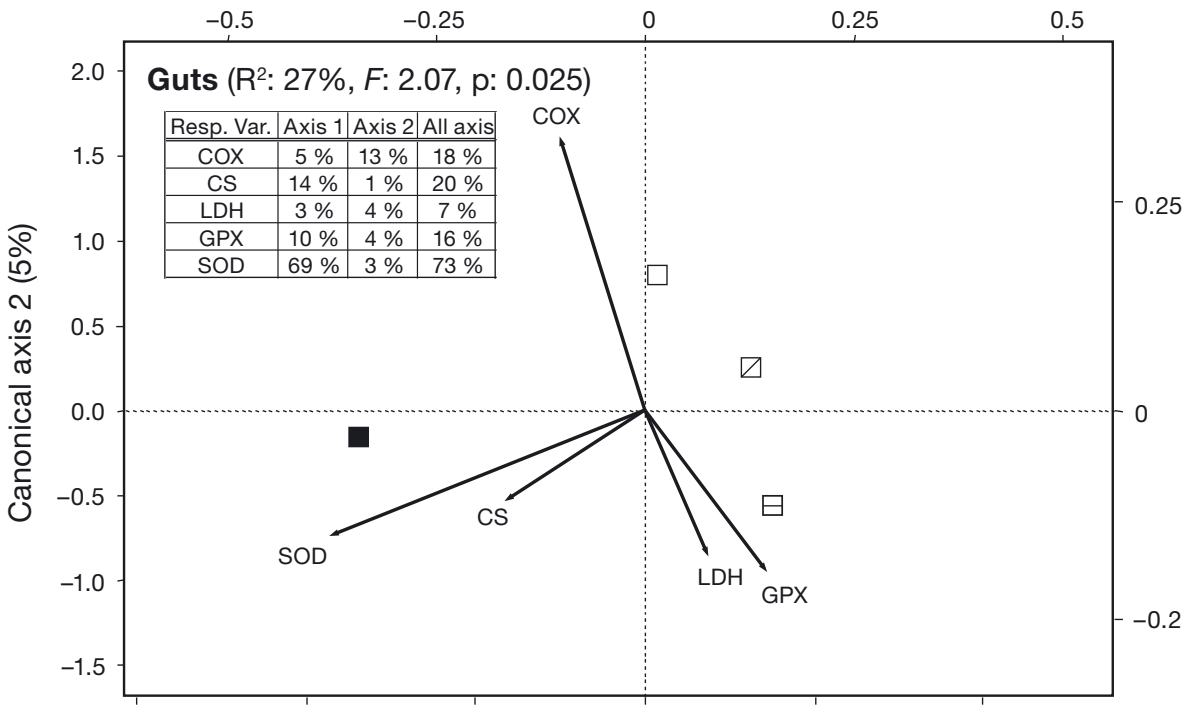

Canonical axis $1(20 \%)$

Fig. 3. Alvinella pompejana. Redundancy analysis biplots representing the effect of vent sites on metabolic and antioxidant enzymatic activities (response centage of explained variance of the enzyme activity among sites $\left(\mathrm{R}^{2}\right)$ as well as the significance is shown in each panel. See Table 1 for enzyme abbreviations variables, arrows) in 2 tissues where the differences were significant. The per-

water polychaetes, it is likely that $P$. grasslei and A. pompejana compensate their very low CAT and low GPX activities by increasing levels of other peroxidases. Peroxiredoxins (PRDXs) are a recently discovered class of ubiquitous peroxidases expressed in all animal cells (Rhee et al. 2001, Shuvaeva et al. 2009). These thiol-based antioxidant proteins are insensitive to sulphide and, on the contrary, some PRDX family members use $\mathrm{H}_{2} \mathrm{~S}$ as a physiological reductant (Peshenko \& Shichi 2001, Loumaye et al. 2011). The presence of such a mechanism in alvinellids would detoxify both peroxides and sulphides, bringing advantages in comparison to other peroxidases. Beside the possible utilisation of $\mathrm{H}_{2} \mathrm{~S}$, the endowment of chaperone activity by some of the PRDX family members could have favoured their selection in these thermophilic animals, as suggested by the presence of PRDX-related cDNA in A. pompejana (Gagnière et al. 2010). It is also noteworthy that alkyl hydroperoxide reductase (AhpC), the bacterial homologue of PRDXs, is strongly induced in $R$. pachyptila symbionts experimentally exposed to $\mathrm{H}_{2} \mathrm{O}_{2}$ (Markert et al. 2007). This supports the possible role of PRDXs as important peroxide detoxification mechanisms in hydrothermal vent organisms, including $A$. pompejana.

The high SOD activity present in all tissues of Alvinella pompejana a does not appear to target respiration-derived ROS as no correlation was found between SOD and metabolic enzyme activities. Other sources of $\mathrm{O}_{2}{ }^{--}$, not directly associated with the metal-catalysed reactions, or by sulphur amino acids known to be present at high concentrations in the tissues of hydrothermal animals (Yin et al. 2000, Brand et al. 2007, Yancey et al. 2009). As in P. grasslei, the virtual absence of CAT activity does not seem to be compensated by higher GPX activity. This could possibly reflect the low threat posed by $\mathrm{H}_{2} \mathrm{O}_{2}$ to these animals, and thus a low resistance of these animals. Since Dixon et al. (2002) reported a similar susceptibility to exogenous $\mathrm{H}_{2} \mathrm{O}_{2}$ for $P$. grasslei and shallow- respiratory chain, might thus be responsible for setting the expression level of SOD between tissues. High SOD activities are often linked to the presence of haemoglobin in invertebrates, possibly reflecting the tendency of these respiratory pigments to form $\mathrm{O}_{2}{ }^{\text {- }}$ via autoxidation (Abele-Oeschger \& Oeschger 1995, Abele-Oeschger 1996, Joyner \& Julian, 2011). It is thus possible that high SOD activity could be required for neutralising superoxide associated with the oxidation of haemoglobin, particularly abundant 
in alvinellids. Moreover, Julian et al. (2005) have demonstrated that oxidative stress and superoxide production in the sulphide-tolerant annelid Glycera dibranchiate was associated with mitochondrial depolarisation following $\mathrm{H}_{2} \mathrm{~S}$ exposure. In this context, the high SOD activity measured in gills in the present study could be associated with the presence of $\mathrm{H}_{2} \mathrm{~S}$ in this tissue. Another possibility is that this remarkably high level of SOD activity could be related to the presence of metallic ions within the tissues, especially important in gut contents, and would directly serve to detoxify superoxide formed by the transition metal ion Fenton reaction.

\section{Relationship between metabolic and antioxidant activities}

The COX and LDH activities measured in this study are within the same range as those reported in previous works on Alvinella pompejana (Hand \& Somero 1983, Desbruyères et al. 1998). Activity levels of all metabolic enzymes varied markedly between tissues. Gills showed the highest CS, COX and LDH activities, suggesting that this tissue is the most metabolically active tissue of $A$. pompejana. Similar results were found in the paralvinellid worms Paralvinella palmiformis and P. sulfincola by Rinke \& Lee (2009) and previously in P. grasslei by Marie et al. (2006). For the first 2 species, the lower CS associated with higher anaerobic activities in the body wall in comparison to the gills was ascribed to an extensive contribution of anaerobic pathways in body wall muscles.

Analysis of the relationships of antioxidant enzymes with aerobic metabolism showed that GPX, but not SOD activity, correlated with COX and CS activities in all tissues. This indicates that $\mathrm{H}_{2} \mathrm{O}_{2}$ production by the mitochondrial electron transport chain sets the expression level of GPX. Similar correlations between GPX and metabolic enzymes have been reported for Paralvinella grasslei (Marie et al. 2006), indicating that GPX has no particular status in these hydrothermal annelids and is adjusted to the endogenous ROS production rate by oxidative metabolism, as classically observed in other marine organisms (Janssens et al. 2000, Marie et al. 2006). Surprisingly, good correlation was found between LDH and GPX. The reason for this correlation remains unclear. Recently, beside its involvement in anaerobic energy production, LDH has been shown to play an important role in the regulation of the redox balance of cells which are known to regulate the activity of GPX (Ying 2008, Ramanathan et al. 2009).

\section{Inter-vent variations}

Variations in enzyme activities between venting sites could be indicative of the influence of the chemical environment on worm physiology. Unfortunately, in the present study we did not record precise data on differences in temperature regime, fluid chemistry or metal accumulation by Alvinella pompejana at the 4 sampled sites. Nevertheless, data collected by Matabos et al. (2008) and Matabos \& Thiebaut (2010) during the same campaign indicated that the Parigo site was characterised by high sulphides and low iron concentrations, while the Elsa site possessed the opposite characteristics with low sulphides and high iron concentrations. Interestingly, Bebianno et al. (2005) have reported significant influence of the vent field on SOD, CAT and GPX activities of Bathymodiolus azoricus. They ascribe these differences to the site-specific metal accumulation and to the chemical composition of the hydrothermal fluid. In $B$. azoricus, gill levels of SOD, CAT and GPX were correlated with $\mathrm{Mn}, \mathrm{Fe}$ and $\mathrm{Cd}$, respectively. In our data, although the SOD activity in gills was slightly higher in the iron-rich site Elsa (Elsa: $1954 \pm 338 \mathrm{U} \mathrm{g}^{-1}$ wet $w_{\text {; }}$ Parigo: $1240 \pm 286 \mathrm{U} \mathrm{g}^{-1}$ wet wt), the most important difference in SOD activity between the both sites was recorded in gut samples. In this tissue, the SOD activity was approximately 2-fold higher in animals from Elsa, reflecting site-related differences in the metal content of the guts, as observed by Desbruyères et al. (1998). All of these elements suggest a putative effect of metal content, especially $\mathrm{Fe}$, on the SOD activity in the gills and guts, but specific concentrations of metal content in tissues are required to validate this hypothesis. Beside the side effect on SOD, our results also revealed that worms from Parigo exhibited the highest energetic metabolism (CS and COX) and GPX activities in gills. With regard to the high sulphide concentration recorded at Parigo by Matabos et al. (2008) and Matabos \& Thiebaut (2010), this suggests that gills exposed to high sulphide concentrations develop more metabolic abilities. This physiological change could be considered as a compensatory response to the inhibiting effect of sulphide on aerobic metabolism. More precisely, if we assume that CS and COX activities are correlated to the mitochondrial content (Larsen et al. 2012), we can hypothesise that animals exposed to higher sulphide concentrations increase their mitochondrial density in gills in order to ensure accurate energetic metabolism. The impact of sulphide on the energetic metabolism of annelids has been well documented (see review of Joyner \& Julian 2011) but, to 
our knowledge, the impact on the mitochondrial density has never been investigated and requires further study to validate this hypothesis.

\section{CONCLUSION}

To conclude, these results suggest that Pompeii worms present a rather peculiar antioxidant arsenal, with little or no CAT-like activity and high SOD levels. This high superoxide detoxification potential could not be linked to oxidative metabolism, indicating that non-respiratory mechanisms, possibly the abundance of haemoglobin or metal ions, underlie the higher requirements for SOD. The high SOD would in turn generate high levels of $\mathrm{H}_{2} \mathrm{O}_{2}$ which are unlikely to be catabolised by either the very low CAT or the low GPX activities. Other sulphide-resistant peroxidases, such as peroxiredoxins, could be more effective in preventing SOD-generated $\mathrm{H}_{2} \mathrm{O}_{2}$ entering Fentonlike production of hydroxyl radicals in a metal-rich environment. Finally, some inter-site variations were measured in gills and guts, reflecting probably differences in the physico-chemical conditions of vents, especially in sulphide and metal content.

Acknowledgements. The authors thank the captains and the crews of the N/O 'L'Atalante' and ROV Victor 6000. We are also very grateful to N. Le Bris and F. Gaill, the chief scientists of the French research cruise PHARE'02. This study was supported by the French Ministère des affaires étrangères under the Integrated Program Action called Tournesol ( $\mathrm{N}^{\circ}$ 05365GT) and the Belgian Fonds National de la Recherche Scientifique (Fonds de la Recherche Fondamentale Collective, FRFC).

\section{LITERATURE CITED}

Abele-Oeschger D (1996) A comparative study of superoxide dismutase activity in marine benthic invertebrates with respect to environmental sulphide exposure. J Exp Mar Biol Ecol 197:39-49

- Abele-Oeschger D, Oeschger R (1995) Hypoxia-induced autoxidation of haemoglobin of the benthic invertebrates Arenicola marina (Polychaeta) and Astarte borealis (Bivalvia) and the possible effects of sulphide. J Exp Mar Biol Ecol 187:63-80

> Adly AAM (2010) Oxidative stress and disease: an updated review. Res J Immunol 3:129-145

> Bebianno MJ, Company R, Serafim A, Camus L, Cosson RP, Fiala-Medoni A (2005) Antioxidant systems and lipid peroxidation in Bathymodiolus azoricus from MidAtlantic Ridge hydrothermal vent fields. Aquat Toxicol 75:354-373

Beers RF Jr, Sizer IW (1954) Sulfide inhibition of catalase. Science 120:32-33

Benetti LR, Campos D, Gurgueira SA, Vercesi AE and others
(2013) Hydrogen sulfide inhibits oxidative stress in lungs from allergic mice in vivo. Eur J Pharmacol 698:463-469

- Blum J, Fridovich I (1984) Enzymatic defenses against oxygen toxicity in hydrothermal vent animals Riftia pachyptila and Capyptogena magnifica. Arch Biochem Biophys 228:617-620

Brand GL, Horak RV, Le Bris N, Goffredi SK, Carney SL, Govenar B, Yancey PH (2007) Hypotaurine and thiotaurine as indicators of sulfide exposure in bivalves and vestimentiferans from hydrothermal vents and cold seeps. Mar Ecol 28:208-218

> Carlsson J, Berglin EH, Claesson R, Edlund MBK, Persson S (1988) Catalase inhibition by sulfide and hydrogen peroxide-induced mutagenicity in Salmonella typhimurium strain TA102. Mutat Res 202:59-64

Cary SC, Shank T, Stein JR (1998) Worms bask in extreme temperatures. Nat Chem 391:545-546

Childress JJ, Somero GN (1979) Depth-related enzyme activities in muscle, brain and heart of deep-living pelagic marine teleosts. Mar Biol 52:273-283

Company R, Serafim A, Bebianno MJ, Cosson R, Shillito B, Fiala-Medioni A (2004) Effect of cadmium, copper and mercury on antioxidant enzyme activities and lipid peroxidation in the gills of the hydrothermal vent mussel Bathymodiolus azoricus. Mar Environ Res 58:377-381

Company R, Serafim A, Cosson R, Camus L, Shillito B, FialaMedioni A, Bebianno MJ (2006a) The effect of cadmium on antioxidant responses and the susceptibility to oxidative stress in the hydrothermal vent mussel Bathymodiolus azoricus. Mar Biol 148:817-825

Company R, Serafim A, Cosson R, Fiala-Medioni A, Bebianno MJ (2006b) Evaluation of antioxidant defence system in transplanted mussels from two Mid-Atlantic Ridge hydrothermal vents. Mar Environ Res 62: S444-S445

Company R, Serafim A, Cosson R, Fiala-Medioni A, Dixon D, Bebianno MJ (2006c) Temporal variation in the antioxidant defence system and lipid peroxidation in the gills and mantle of hydrothermal vent mussel Bathymodiolus azoricus. Deep-Sea Res I 53:1101-1116

Company R, Serafim A, Cosson R, Fiala-Medioni A, Dixon DR, Bebianno MJ (2007) Adaptation of the antioxidant defence system in hydrothermal-vent mussels (bathymodiolus azoricus) transplanted between two MidAtlantic Ridge sites. Mar Ecol 28:93-99

- Company R, Serafim A, Cosson RP, Fiala-Médioni A and others (2008) Antioxidant biochemical responses to longterm copper exposure in Bathymodiolus azoricus from Menez-Gwen hydrothermal vent. Sci Total Environ 389: 407-417

Company R, Serafim A, Cosson RP, Fiala-Medioni A, Camus L, Serrao-Santos R, Bebianno MJ (2010) Sub-lethal effects of cadmium on the antioxidant defence system of the hydrothermal vent mussel Bathymodiolus azoricus. Ecotoxicol Environ Saf 73:788-795

Cosson RP, Thiébaut É, Company R, Castrec-Rouelle M and others (2008) Spatial variation of metal bioaccumulation in the hydrothermal vent mussel Bathymodiolus azoricus. Mar Environ Res 65:405-415

Demina LL, Holm NG, Galkin SV, Lein AY (in press) Some features of the trace metal biogeochemistry in the deepsea hydrothermal vent fields (Menez Gwen, Rainbow, Broken Spur at the MAR and 9 ${ }^{\circ} 50^{\prime} \mathrm{N}$ at the EPR): a synthesis. J Mar Syst

Desbruyères $\mathrm{D}$, Chevaldonné $\mathrm{P}$, Alayse AM, Jollivet D and 
others (1998) Biology and ecology of the 'Pompeii worm' (Alvinella pompejana Desbruyères and Laubier), a normal dweller of an extreme deep-sea environment: a synthesis of current knowledge and recent developments. Deep-Sea Res II 45:383-422

Di Meo-Savoie CA, Luther GW, Cary SC (2004) Physicochemical characterization of the microhabitat of the epibionts associated with Alvinella pompejana, a hydrothermal vent annelid. Geochim Cosmochim Acta 68: 2055-2066

Dixon DR, Dixon LRJ, Shillito B, Gwynn JP (2002) Background and induced levels of DNA damage in pacific deep-sea vent polychaetes: the case for avoidance. Cah Biol Mar 43:333-336

> Fisher CR, Takai K, Le Bris N (2007) Hydrothermal vent ecosystems. Oceanography 20:14-23

> Flohé L, Ötting F (1984) Superoxide dismutase assays. Methods Enzymol 105:93-104

Gagnière N, Jollivet D, Boutet I, Brélivet Y and others (2010) Insights into metazoan evolution from Alvinella pompejana cDNAs. BMC Genomics 11:634

> Giles GI, Tasker KM, Collins C, Giles NM, O'Rourke E, Jacob C (2002) Reactive sulphur species: an in vitro investigation of the oxidation properties of disulphide S-oxides. Biochem J 364:579-585

Gruhlke MCH, Slusarenko AJ (2012) The biology of reactive sulfur species (RSS). Plant Physiol Biochem 59:98-107

> Halliwell B, Gutteridge JMC (1986) Oxygen free radicals and iron in relation to biology and medicine: some problems and concepts. Arch Biochem Biophys 246: 501-514

> Hand SC, Somero GN (1983) Energy metabolism pathways of hydrothermal vent animals: adaptations to a food-rich and a sulfide-rich deep-sea environment. Biol Bull 165: $167-181$

> Hourdez S, Lallier FH, De Cian MC, Green BN, Weber RE, Toulmond A (2000) Gas transfer system in Alvinella pompejana (Annelida Polychaeta, Terebellida): functional properties of intracellular and extracellular hemoglobins. Physiol Biochem Zool 73:365-373

> Janssens BJ, Childress JJ, Baguet F, Rees JF (2000) Reduced enzymatic antioxidative defense in deep-sea fish. J Exp Biol 203:3717-3725

Jouin-Toulmond C, Augustin D, Desbruyères D, Toulmond A (1996) The gas transfer system in alvinellids (Annelida Polychaeta, Terebellida). Anatomy and ultrastructure of the anterior circulatory system and characterization of a coelomic, intracellular, haemoglobin. Cah Biol Mar 37: 135-151

Joyner-Matos J, Julian D (2011) Oxidative stress in sulfidic Habitats. In: Abele D, Vázquez-Medina JP, ZentenoSavín $\mathrm{T}$ (eds) Oxidative stress in aquatic ecosystems. John Wiley \& Sons, Chichester p 99-114

Julian D, April KL, Patel S, Stein JR, Wohlgemuth SE (2005) Mitochondrial depolarization following hydrogen sulfide exposure in erythrocytes from a sulfide-tolerant marine invertebrate. J Exp Biol 208:4109-4122

Larsen S, Nielsen J, Hansen CN, Nielsen LB and others (2012) Biomarkers of mitochondrial content in skeletal muscle of healthy young human subjects. J Physiol 590: 3349-3360

Le Bris N, Gaill F (2007) How does the annelid Alvinella pompejana deal with an extreme hydrothermal environment? Rev Environ Sci Biotechnol 6:102-119

Le Bris N, Zbinden M, Gaill F (2005) Processes controlling the physico-chemical micro-environments associated with Pompeii worms. Deep-Sea Res I 52:1071-1083

Le Bris N, Govenar B, Le Gall C, Fisher CR (2006) Variability of physico-chemical conditions in $9^{\circ} 50^{\prime} \mathrm{N}$ EPR diffuse flow vent habitats. Mar Chem 98:167-182

Legendre P, Anderson MJ (1999) Distance-based redundancy analysis: testing multispecies responses in multifactorial ecological experiments. Ecol Monogr 69:1-24

Legendre P, Legendre L (2012) Numerical ecology, 3rd English edn. Developments in environmental modelling, Vol 24. Elsevier Science, Amsterdam

- Loumaye E, Ferrer-Sueta G, Alvarez B, Rees JF and others (2011) Kinetic studies of peroxiredoxin 6 from Arenicola marina: rapid oxidation by hydrogen peroxide and peroxynitrite but lack of reduction by hydrogen sulfide. Arch Biochem Biophys 514:1-7

Lowry OH, Rosebrough NJ, Farr AL, Randall RJ (1951) Protein measurement with the Folin phenol reagent. J Biol Chem 193:265-275

> Marie B, Genard B, Rees JF, Zal F (2006) Effect of ambient oxygen concentration on activities of enzymatic antioxidant defences and aerobic metabolism in the hydrothermal vent worm, Paralvinella grasslei. Mar Biol 150: 273-284

> Markert S, Arndt C, Felbeck H, Becher D and others (2007) Physiological proteomics of the uncultured endosymbiont of Riftia pachyptila. Science 315:247-250

> Matabos M, Thiebaut E (2010) Reproductive biology of three hydrothermal vent peltospirid gastropods (Nodopelta heminoda, N. subnoda and Peltospira operculata) associated with Pompeii worms on the East Pacific Rise. J Molluscan Stud 76:257-266

- Matabos M, Le Bris N, Pendlebury S, Thiébaut E (2008) Role of physico-chemical environment on gastropod assemblages at hydrothermal vents on the East Pacific Rise (13ํN/EPR). J Mar Biol Assoc UK 88:995-1008

Paglia DE, Valentine WN (1967) Studies on the quantitative and qualitative characterization of erythrocyte glutathione peroxidase. J Lab Clin Med 70:158-169

Peshenko IV, Shichi H (2001) Oxidation of active center cysteine of bovine 1-cys peroxiredoxin to the cysteine sulfenic acid form by peroxide and peroxynitrite. Free Radical Biol Med 31:292-303

Pradillon F, Zbinden M, Mullineaux LS, Gaill F (2005) Colonisation of newly-opened habitat by a pioneer species, Alvinella pompejana (Polychaeta: Alvinellidae), at East Pacific Rise vent sites. Mar Ecol Prog Ser 302:147-157

> Pradillon F, Zbinden M, Le Bris N, Hourdez S, Barnay AS, Gaill F (2009) Development of assemblages associated with alvinellid colonies on the walls of high-temperature vents at the East Pacific Rise. Deep-Sea Res II 56: 1622-1631

- Ramanathan R, Mancini RA, Konda MR (2009) Effects of lactate on beef heart mitochondrial oxygen consumption and muscle darkening. J Agric Food Chem 57:1550-1555

> Rhee SG, Kang SW, Chang TS, Jeong W, Kim K (2001) Peroxiredoxin, a novel family of peroxidases. IUBMB Life 52:35-41

Rinke C, Lee RW (2009) Pathways, activities and thermal stability of anaerobic and aerobic enzymes in thermophilic vent paralvinellid worms. Mar Ecol Prog Ser 382:99-112

Schöneich C, Asmus KD, Dillinger U, von Bruchhausen F (1989) Thiyl radical attack on polyunsaturated fatty acids: a possible route to lipid peroxidation. Biochem 
Biophys Res Commun 161:113-120

Shuvaeva TM, Novoselov VI, Fesenko EE, Lipkin VM (2009) Peroxiredoxins, a new family of antioxidant proteins. Russ J Bioorganic Chem 35:523-537

Thuesen EV, Childress JJ (1993) Metabolic rates, enzyme activities and chemical compositions of some deep-sea pelagic worms, particularly Nectonemertes mirabilis (Nemertea; Hoplonemertinea) and Poeobius meseres (Annelida; Polychaeta). Deep-Sea Res I 40:937-951

> Thuesen EV, Childress JJ (1994) Oxygen consumption rates and metabolic enzyme activities of oceanic California medusae in relation to body size and habitat depth. Biol Bull 187:84-98

Tweeddale HJ, Kondo M, Gebicki JM (2007) Proteins protect lipid membranes from oxidation by thiyl radicals. Arch Biochem Biophys 459:151-158

Völkel S, Grieshaber MK (1997) Sulphide oxidation and

Editorial responsibility: Wen-Xiong Wang,

Kowloon, Hong Kong, SAR oxidative phosphorylation in the mitochondria of the lugworm Arenicola marina. J Exp Biol 200:83-92

Yancey PH, Ishikawa J, Meyer B, Girguis PR, Lee RW (2009) Thiotaurine and hypotaurine contents in hydrothermalvent polychaetes without thiotrophic endosymbionts: correlation with sulfide exposure. J Exp Zool A Ecol Genet Physiol 311:439-447

Yin M, Palmer HR, Fyfe-Johnson AL, Bedford JJ, Smith RAJ, Yancey PH (2000) Hypotaurine, N-methyltaurine, taurine, and glycine betaine as dominant osmolytes of vestimentiferan tubeworms from hydrothermal vents and cold seeps. Physiol Biochem Zool 73:629-637

Ying $\mathrm{W}(2008) \mathrm{NAD}^{+} / \mathrm{NADH}$ and $\mathrm{NADP}^{+} / \mathrm{NADPH}$ in cellular functions and cell death: Regulation and biological consequences. Antioxid Redox Signal 10:179-206

Yonetani T (1967) Cytochrome oxidase: Beef heart. Methods Enzymol 10:332-335

Submitted: August 14, 2012; Accepted: January 29, 2013 Proofs received from author(s): April 26, 2013 